\title{
The need to enhance the employability competences (knowledge, skills, autonomy, and attitudes) of undergraduates in Agriculture. Evidence from students' perceptions and employers' expectations
}

\author{
Nigel Yoven Armoogum, Brinda Ramasawmy, and Brigitte Marie \\ Françoise Driver*
}

doi: http://dx.doi.org/10.18543/tjhe-4(1)-2016pp169-219

\begin{abstract}
The Faculty of Agriculture (FoA) (University of Mauritius) is the only tertiary Education Institution in the country providing graduate training in Agriculture with an annual enrolment of about 100-125 students. Although the relative contribution of the Agricultural sector to the economy has declined over the past decade - share to GDP: $3.0 \%$ in 2014 as compared to $6.4 \%$ in $2004^{1}$ the introduction of new schemes in support of Bio- Farming, food processing and value-addition will attract new entrepreneurs to Agriculture. This transformation in the Agriculture sector will create new job opportunities, but has to leverage on skilled human capital. Graduates with good employability skills are of strategic importance to the FoA, in line with the government's vision to develop a knowledge-based economy. This study aimed at mapping out the set of skills, understandings and personal attributes that will increase the job prospects of the fresh graduate from FoA in Agriculture. The main research question centred on the perceptions of employers, alumni and students of the FoA, concerning the most relevant competences for the Subject Area (key general and key subject specific competences), understandings and personal attributes, which enhance
\end{abstract}

* Nigel Yoven Armoogum (nigel.armoogum@umail.uom.ac.mu), BSc (Hons.) in Agriscience and Technology, has a keen interest in the competences and skills that are required by the graduates of the Faculty of Agriculture (FoA) of the University of Mauritius (Mauritius) to match the expectations of employers in terms of employability of young and fresh graduates.

Brinda Ramasawmy (b.ramasawmy@uom.ac.mu), PhD in Management Sciences, a lecturer in the area of agricultural economics and management in the Department of Agricultural Production and Systems at the Faculty of Agriculture (University of Mauritius).

Brigitte Marie Françoise Driver (mfdriver@uom.ac.mu), PhD in Animal Science, is Associate Professor at the Faculty of Agriculture (University of Mauritius) and Senior African Research Fulbright Fellow.

More details on the authors are provided at the end of this article.

1 "Digest of Agricultural Statistics Mauritius," Ministry of Finance and Economic Development, http://statsmauritius.govmu.org/English/StatsbySubj/Documents/Digest/ Digest $\% 20$ of\%20Agricultural\%20Statistics\%202014.pdf. 
the employability of graduates in Agriculture. Using semi-structured interviews, the study explored and triangulated the perceptions from four key stakeholders' perspectives, namely: a range of employers, Industry Placement Supervisors, alumni of the FoA and current students. Both quantitative and qualitative insights of the perceptions on the employability skills of FoA undergraduates were obtained from a wide range of employers from the private and public sector. An analysis of data from the interviews and responses was carried out using SPSS. The key attributes that were valued by the key stakeholders have been used to inform the 'Employability Skills Subject Area Framework', and the 'Curriculum Mapping', proposed for the degree of BSc (Hons) Agriscience and Technology of the FoA.

Keywords: undergraduate; agriculture; employability; generic and subject specific competences (knowledge, skills and autonomy and responsibility); curriculum mapping.

This work was carried out at the Faculty of Agriculture of the University of Mauritius, Mauritius. The authors would like to thank all the different employers in the Mauritian agricultural sector for their time and collaboration, as well as all the students (current and alumni) and staff who participated in the surveys.

\section{Introduction}

Education, worldwide, has known a lot of innovation, modernisation and has greatly evolved since time immemorial. All countries around the world have understood the importance of education for the development of a country, for the improvement of their Gross Domestic Product (GDP) and for valueaddition to their own labour force. With the occurrence of competition for meritocracy in workplace, more and more students around the world are going for tertiary education. Thus, there has been a tremendous increase in the number of students leaving university with a degree, and with the emergence of these graduates, additional pressure is added on the government and the states to employ them. Recent studies by the World Bank show that the global employment rate has increased from $43 \%$ in 2005 to $63 \%$ in 2007 . Even though unemployment scaled down by 7 points (around $9 \%$ in 2007), it remained nonetheless at a pre-occupying level towards the end of 2007: it still concerns about $29 \%$ of university graduates three years and a half after their graduation ${ }^{2}$

2 World Bank, "Education, Quality and Economic Growth" (2007). http://siteresources. worldbank.org/EDUCATION/Resources/278200-1099079877269/547664-1099079934475/ Edu_Quality_Economic_Growth.pdf. 
and almost 74 million people in the 15 to 24 age group unemployed around the world, translating into a 12.4 per cent unemployment rate for this subset.

\section{I.1. Rationale for the study}

The $\mathrm{OECD}^{3}$ identifies four main ways in which tertiary education contributes to the social and economic development of a country. Firstly, value-addition to human capital through teaching; secondly, the use of research and the development of knowledge to build knowledge bases; thirdly, fostering interactions with knowledge users to disseminate and use knowledge; and fourthly, the maintenance of knowledge through inter-generational storage and the transmission of knowledge thereon. With increasing globalised competition for jobs and promotion of lifelong learning opportunities, it is important that Tertiary Education Institutions (TEIs) establish a closer link between learning opportunities and the employability skills and competences required in the workplace. Employability of a student leaving University with a degree should be a key preoccupation of TEIs the more so as the tertiary education sector is becoming a highly competitive one with students having the possibility to choose from the wide array of institutions both within a country and internationally. The advent of e-learning facilities offers even more opportunities for students to modulate their tertiary education according to their needs and preferences. It is therefore important that TEIs update the employability skills that are being transferred to students through their programmes of studies to be in line with the demand of the job market.

Therefore the general aim of this study is to assess the need of TEIs to enhance the employability skills of undergraduate students in the field of Agriculture based on what current and past students perceive to be important and the expectations of the current and potential employers. Degree programmes in Agriculture are designed to develop the competences required of graduates who will be involved in the management of agricultural enterprises, research and advisory work. Graduates from Agricultural degrees are expected to acquire a thorough understanding of crop and animal production techniques and of the underpinning scientific, economic and business principles for the production of safe food in a sustainable manner. Graduates in Agriculture will be able to identify and solve technological

${ }^{3}$ OECD, "Tertiary Education for the Knowledge Society: OECD Thematic Review of Tertiary Education: Synthesis Report" (2008), accessed August 11, 2016, http:// oecdconference-teks.iscte.pt/downloads/OECD_overview.pdf. 
problems encountered in typical production systems, to evaluate new technologies and apply them to commercial practice, to manage an agribusiness, to respond to public concerns for safe food production practices and to evaluate the consequences of agriculture on the environment.

\section{I.2. The context of the study}

This study was conducted in the Republic of Mauritius, and most specifically on the main island Mauritius, a small island state located in the Indian Ocean and East of Madagascar with a current population of around 1.2 million inhabitants in December 2015. ${ }^{4}$ The following sections provide a brief description of the job market in Mauritius as well as the role of Tertiary Education Institutions in providing graduates for the job market.

\section{I.2.1. The job market in Mauritius}

Mauritius became independent in 1968 and since then, the unemployment rate of the Mauritian population has been quite low, the highest rate of unemployment (19.70\%) being recorded in 1983. ${ }^{5}$ However, with the economic boom that was initiated with the tourism and textile industry, the unemployment rate declined to $2.70 \%$ in the 1990 s.

Mauritius has been recently described as the emerging country of the Indian Ocean with the brightest future. Mauritius being a developing country has an unemployment rate of $7.8 \%$, that is, about 16280 inhabitants are unemployed. ${ }^{6}$ In order to decrease this unemployment rate, the Mauritian government has adopted the "YEP project" (Youth Employment Program). Hence in 2013, about 4000 youths were attributed a job in the private and the public sector as well. In addition, the Ministry of Finance aims at setting up a training program entitled "Service-focused employment preparation" that

4 "Digest of Agricultural Statistics Mauritius," Ministry of Finance and Economic Development, http://statsmauritius.govmu.org/English/StatsbySubj/Documents/Digest/ Digest\%20of\%20Agricultural\%20Statistics\%202014.pdf.

${ }^{5}$ Central Statistics Office (Mauritius), "Mauritius in Figures," Ministry of Finance and Economic Development, http://statsmauritius.govmu.org/English/Publications/Documents/ $\mathrm{MIF} / \mathrm{mif09.pdf}$

6 "Statistics Mauritius", Ministry of Finance and Economic Development 2015, http:// statsmauritius.govmu.org/English/StatsbySubj/Documents/Digest/Digest $\% 20$ of\% 20 Agricultural\%20Statistics\%202014.pdf. 
would improve the "soft skills" of unemployed youth to enable them to be more effective at work.

The Mauritian Agricultural sector represents 19\% of employment of the country's population. The other sectors of the population are employed in the EPZ sector (33.9\%), $12.6 \%$ in the manufacturing sector, $16.5 \%$ works in the tourism industry and $8.3 \%$ works in the financial services. ${ }^{7}$

\section{I.2.2. The training role of Tertiary Education Institutions for the job market in Mauritius}

The tertiary education landscape in Mauritius has witnessed major changes since its independence in 1968, when only the University of Mauritius was offering tertiary education. Today, there are 68 Tertiary Education Institutions operating in Mauritius. There are 10 publicly-funded Tertiary Education Institutions, including 4 universities and 6 institutions. Each has its own specificity, and offers programmes in diverse fields of study, ranging from Certificate to $\mathrm{PhD}$ level. In addition, 58 private tertiary institutions are registered locally and provide tertiary education. The awarding bodies of the private tertiary institutions are mostly based overseas. However, the University of Mauritius is the only Tertiary Education Institution in Mauritius offering undergraduate and postgraduate courses in Agriculture. The Faculty of Agriculture is the foundation Faculty of the University of Mauritius. It was originally founded as the College of Agriculture of the Ministry of Agriculture in 1914. In 2014, the Faculty has celebrated a century of teaching and training in the agricultural and food sectors in Mauritius.

At the end of 2013, 42,000 Mauritian students were enrolled in a study programme at tertiary level, out of which $55 \%$ were female students. The distribution of those students across different fields of study ${ }^{8}$ were Education (8\%), Humanities and Arts (5.4\%), Social Sciences, Business and Law $(54.9 \%)$, Sciences $(11.9 \%)$; Engineering, Manufacturing and Construction $(7.5 \%)$, Agriculture $(0.9 \%)$, Health and Welfare $(4.8 \%)$, Services $(5.2 \%)$ and Others $(1.4 \%)$. It is to be noted that students' enrolment in the field of Agriculture is quite low and has been on a constant decline over the years with an increasing preference for social sciences, business and law.

${ }^{7}$ Pierre Dinan, "The agricultural sector in Mauritius: Economic aspects-Past, present and future." Presented at the Symposium on Agriculture in Mauritius: Evolution and Prospects on 29th October 2003, Mauritius Chamber of Agriculture, www.mchagric.org/images/pdf/p_dinan.pdf

${ }^{8}$ UNESCO, "The 2015 Global Monitoring Report - Education for All 2000-2015: Achievements and Challenges," http://unesdoc.unesco.org/images/0023/002322/232205e.pdf. 


\section{I.2.2.1. Linking the Faculty of Agriculture to the Mauritian agricultural sector}

The Faculty of Agriculture (University of Mauritius) is committed to the advancement of Teaching and Learning in the areas of Agriculture and food. The Faculty has engaged in the development of a comprehensive portfolio of new programmes of studies at Certificate, Diploma, $\mathrm{BSc}$ and $\mathrm{PhD}$ level during the period 2006-2015, including food science and technology, food safety and quality, agricultural science and technology, bio-farming, natural resource management, aquaculture, agribusiness, agricultural extension, land and water management, landscape management, biotechnology, microbiology, applied biochemistry, bioinformatics etc. The portfolio of new programmes reflects emerging areas in Agriculture and food in Mauritius, and illustrates how the Faculty has responded to the needs of students and of prospective employers.

\section{I.3. The aims of the study}

The aims of this study are three-fold. First the study aims at analysing and determining the employment status of undergraduates in the field of Agriculture. Second, the aim is to evaluate the contribution of a longstanding programme of studies to the undergraduates' personal knowledge, skills and attributes. Third, the aim is to define further training needs of undergraduates in the field of Agriculture.

The main research questions of the present study are:

-What are the perceptions of employers, alumni and students of the FoA, concerning the skills, understandings and personal attributes, which enhance the employability of undergraduates in Agriculture?

-What are the gaps in perceptions of professional competencies between key stakeholders?

- How can the FoA use the perceptions to provide formal learning opportunities to enhance employability skills of FoA students?

\section{Method}

\section{II.1. Literature review}

A review of some of the most relevant publications on employability, employability skills and competence-based learning was carried out in order be able to answer the research questions of this present study. 
The use of the Tuning methodology helps to identify the relevant generic and subject specific competences of graduates in Agriculture and their interrelations, and contributes to elaborate a meta-profile for the subject. The Tuning methodology contributes to the design of a degree that is relevant to the specific needs of the Republic of Mauritius, the region, and the society at large.

A synthesis of the most important points and concepts are given in the following sections.

\section{II.1.1. Graduate employability and employability skills}

Lees $^{9}$ provided a very interesting comparison between employment and employability. According to her, employment refers to an individual having a job but employability refers to the capacity of an individual to maintain and progress in his/her job and in the job market in general.

According to Hillage and Pollard, ${ }^{10}$ employability refers to the capacity of an individual to first secure initial employment, to be able to keep this employment, and to be eventually able to obtain another employment if required. These authors further add that each individual has employable assets namely knowledge, skills and attitudes. The way the individual uses his/her assets in his search for employment and the context of the job market will impact on his/her employability. Over the last 15 years there has been increasing research interest on graduate employability producing a number of studies (e.g. Atkins; $;{ }^{11}$ Brown; ${ }^{12}$ Archer $;{ }^{13}$ Rothwell $;{ }^{14}$ Stwine and Alves; $;{ }^{15}$

9 Dawn Lees, "Graduate Employability - Literature Review," LTSN Generic Centre. University of Exeter (2002), http://www palatine.ac.uk/files/emp/1233.pdf.

${ }^{10}$ Jim Hillage and Emma Pollard, "Employability: developing a framework for policy analysis," Research Brief No. 85 (London: Department for Education and Employment, 1998).

${ }^{11}$ M J Atkins, "Oven-ready and self-basting: taking stock of employability skills," Teaching in Higher Education 4(2) (1999): 267-280. doi:10.1080/1356251990040208.

${ }_{12}$ Phillip Brown, Anthony Hesketh, and Sara William, "Employability in a knowledgedriven economy," Journal of Education and Work 16(2) (2003):107-126.

13 Will Archer, and Jess Davison, "Graduate employability. What do employers think and want,"(The Council for Industry and Higher Education, UK,2008).

${ }_{14}$ Andrew Rothwell, Steven Jewell, and Marie Hardie, "Self-perceived employability: investigating the responses of post-graduate students," Journal of Vocational Behavior 75 (2009): 152-161.

15 Elinor E Stwine and Mariana G Alves, "Higher Education and employability of graduates: will Bologna make a difference?" European Educational Research Journal 9, no. 1 (2010): 32-44. 
Hodzic ${ }^{16}$ ) with a list of skills and attributes that promote graduate employability namely core skills; key skills; common skills; transferable skills; essential skills; functional skills; skills for life; generic skills and enterprise skills. ${ }^{17}$ Employability ${ }^{18}$ of a graduate has been defined as "the propensity of the graduate to exhibit attributes that employers anticipate will be necessary for the future effective functioning of their organisation." It is important, as pointed out by the National Institute of Adult Continuing Education (NIACE),${ }^{19}$ not to lay emphasis on the responsibility of the individual to be 'employable'. Indeed, NIACE puts forward that employability is a shared 'social construct' between the individuals who have to be responsible for their choices and decisions made and the enterprises who have to provide the adequate work environment and culture (including values, attitudes and behaviours) to promote the employability of their workforce. Rothwell ${ }^{20}$ proposed a student self-perceived employability matrix whereby the student can assess his/her self-perception of his/her employability in relation to interrelated parameters namely his/her self-belief (confidence in his/her skills and abilities, his/her engagement with his/her studies and academic performance, his/her awareness about opportunities in the labour market; his/her own ambitions); his/her university (the student's perception of the strength of the university brand); his/her field of study (the reputation his/her university has in his/her field of study; the status and credibility of his/her field of study; and the state of the external labour market (the student's perception of the state of the external labour market; the demand of the external labour market for his/her field of study).

Graduate employability skills, on the other hand, has been clearly defined $^{21}$ by CBI/Pearson as a set of skills that comprise of a positive attitude to work; self-management; team working; business and customer awareness;

${ }^{16}$ Sabina Hodzic, "Increasing PhD students' employability by focusing on the academic entrepreneurship. The analysis of entrepreneurial competences," Tuning Journal for Higher Education 3, no. 2 (2016): 347-387.

${ }^{17}$ Kevin Lowden, Stuart Hall, Dely Elliott, and Jon Lewin, "Employers' perceptions of the employability skills of new graduates"(Research commissioned by the Edge Foundation, SRCE Centre, University of Glasgow, 2011).

${ }^{18}$ Lee Harvey, "New realities: the relationship between higher education and employment," Tertiary Education and Management 6 (2000): 3-17.

${ }_{19}$ NIACE, http://archive.niace.org.uk/Organisation/advocacy/Archive/Cbipaper.htm.

${ }^{20}$ Andrew Rothwell, Jewell Steven and Marie Hardie, "Self-perceived employability: investigating the responses of post-graduate students," Journal of Vocational Behavior 75 (2009): 152-161.

${ }^{21} \mathrm{CBI} /$ Pearson, "Learning to grow: what employers need from education and skills" (Education and Skills Survey, 2012), www.cbi.org.uk. 
problem solving; analysis skills; basic numeracy skills; application of information technology; knowledge about their chosen job/career; international cultural awareness; and foreign language skills. From the survey carried out ${ }^{22}$ by CBI/Pearson in 2012 on the needs of UK employers from education and skills, it was clear that there were a number of shortcomings identified by the employers such as poor team working; limited career awareness, poor business and customer awareness amongst others. It was put forward by the authors of the report that the shortcomings identified in terms of employability skills can best be overcome through a partnership approach involving the students, the TEIs and the employers.

\section{II.1.2. Competences, Learning Objectives and Learning Outcomes}

It is not within the scope of the present study to provide an exhaustive review of the concept of competence and associated terminologies such as learning objectives and outcomes. However, we wish, in this paper, to base our use of these terminologies on the definitions developed by Tuning given that the Tuning initiatives, namely developing a common communication language amongst stakeholders such as academic staff, students, graduates, employers and professional organisations; and involving those stakeholders in the process of curriculum design and quality enhancement ${ }^{23}$ fit well within the objectives of this present study.

Hence, we use the following definitions of Tuning as proposed by Wagenaar: ${ }^{24}$

- Competences are understood as "a dynamic representation of demonstrated knowledge, understanding/insight/comprehension, (subject specific and generic) intellectual, practical and interpersonal skills and (ethical) values." Competences are owned by the learner, and acquired through the study of successive modules in a course and assessed continuously.

- A learning outcome is referred to as a "statement of what a learner is expected to know, understand and be able to demonstrate after completion of a process of learning."

${ }^{22}$ Ibid.

${ }^{23}$ Robert Wagenaar, 'Competences and learning outcomes: a panacea for understanding the (new) role of Higher Education," Tuning Journal for Higher Education 1, no. 2 (2014): 279-302 (2014).

${ }^{24}$ Ibid. 
- A learning objective refers to the material to be covered by the teaching staff and is therefore based on the transfer of knowledge from the academic staff to the learner.

\section{II.1.2.1. Competence-based learning}

The Faculty of Agriculture of the University of Mauritius has been selected to participate in the TUNING Africa Project, a joint Africa-EU Strategy Tuning project, after a successful application involving 96 universities in Africa. TUNING-Africa is a collaborative process, involving academics working with potential employers and other stakeholders in curriculum development to enhance student competences. The project aims at improving staff capacity to design and develop curricula, working towards the design of a set of reference points for generic competences expected of graduates in Agriculture. The Faculty is confident that the collaborative partnership with institutions in the EU and Africa will enhance opportunities to work towards acquiring or developing further the specialist knowledge, general intellectual skills and capacities, personal qualities and attitudes expected of our graduates in Agriculture and food.

\section{II.2. Sample and procedure}

The secondary and primary data that have been used to inform this present study have come from multiple sources. Hence secondary data was gathered from the registration profile of students in their first year; from previous tracer studies carried out at FoA; from the reports submitted by onsite supervisors of students on industrial placement; and from the current curriculum framework for the course BSc (Hons) Agriscience and Technology. The primary data was gathered from current students at the Faculty of Agriculture of the University of Mauritius; from alumni of FoA; from employers; and from technical staff employed in FoA laboratories. The details of this data collection are explained in the following section.

\section{II.2.1. Secondary Data Collection}

Given that FoA has over 100 years of experience in Higher Education teaching and research in the agricultural sector, we decided for this present study to limit the secondary data collection to a definite period, that is, from 
2000 to 2015 for several reasons namely ease of access to the data as older data were not accessible in a computerised format; curricula at FoA have evolved over the years to respond to the demand from both the public and private sectors in Mauritius and in line with the development of new economic sectors for the country.

First of all the students' admission office of the UoM was contacted to obtain a list of students who have registered for agricultural undergraduate degrees at FoA over the period 2000 to 2015. The aim was to be able to generate a profile of the students based on indicators such as their high school final results and their gender. This profile would be useful to see how A-level students have acquired value over their three year undergraduate study period and the types of employment that they are currently in today.

Secondly the tracer study carried out at FoA for the period 2003-2010 was analysed with respect to its findings and the impact of the latter on curriculum development at FoA.

Thirdly, the reports submitted by on-site supervisors of students on industrial placement were analysed specially in relation to the comments of the supervisors on the performance of the students at the work place.

Fourthly the current curriculum framework used for the BSc (Hons) Agriscience and Technology course was analysed with respect to its modules and module content. The analysis dealt with the learning outcomes, practical skills and other activities that are currently being taught to undergraduate students in Agriculture.

\section{II.2.2. Primary Data Collection}

A series of four quantitative surveys were conducted over the period from November 2015 to February 2016 to gather primary data from different sources namely current students at the Faculty of Agriculture of the University of Mauritius; from alumni of FoA; from employers; and from technical staff employed in FoA laboratories. The survey questionnaires (Annexes C, D, E $\&$ F) gathered information about the competences acquired by FoA undergraduates, their qualities and limitations in the professional environment and improvements thereon.

\section{II.2.3. Sampling}

At the Faculty of Agriculture, there were 5 batches of BSc (Hons) Agriscience and Technology being run in 2015 with about 180 students 
enrolled in this course. Regarding this population size, a sample of 80 students was taken, whereby about 20 students were chosen per course year, (1st year, 2nd year and 3rd year students). 35 past students of FoA were chosen randomly from a list of alumni.

A sample of 16 of the main employers who employ the graduates of the FoA was selected.

A total of 18 technical staff of FoA were selected from all the laboratories of the Faculty namely zoology, botany, microbiology, food science, soil, animal science, biotechnology, biochemistry, tissue culture and at the University Farm.

\section{II.2.4. Data analysis}

The analysis of the data and information gathered was done using various softwares and online softwares. All primary data was fed into the Software package for statistical analysis (SPSS) program. Using the SPPS, various parameters were determined and analysed. 'Google Forms' were used to analyse data online, and past University students were sent mail containing the link for the questionnaire survey. Graphs and other statistical figures were obtained from this online software. Qualitative data found in the surveys, questionnaires and other reports were analysed and then regrouped into categories and themes where each theme explained what the data were in relation with each specific theme.

A gap analysis refers to approaches that quantify the separation from the present state to an objective. ${ }^{25} \mathrm{~A}$ comparison between the results obtained from the employers' point of view and from the alumni point of view about the missing learning competences as well as the competences and skills required for the employability of students graduating from the FoA was made.

\section{II.2.4.1. Analysis of past tracer study at FoA}

In June 2010, a survey was carried out with graduates to evaluate the training provided by the Faculty of Agriculture and to obtain a feedback on

25 John Murray, “A Gap Analysis Process to improve IT management” in The gap Analysis Process; Practical Example; Process Goals and Hurdles; Process Mechanics (2000). Auerbach Publications. CRC Press LLC. http://www.ittoday.info/AIMS/Information_ Management/1-04-35.pdf. 
the pros and cons of the training. The objectives of this study were defined as follows:

- To analyse and to determine the employment status of graduates from the FOA.

- To evaluate the contribution of the programmes of studies to the graduate's personal knowledge, skills and attitudes.

- To define further training needs of graduates.

- To identify the pros and cons of the training undergone at the faculty.

The main important information that can be extracted from the tracer study is detailed out below. Out of 398 past graduates, the employment rate had reached a percentage of $88 \%$ in 2010 (Figure 1). From those $88 \%$ of student who have been employed, about $50 \%$ of them have found employment in the first year after their graduation. ${ }^{26}$

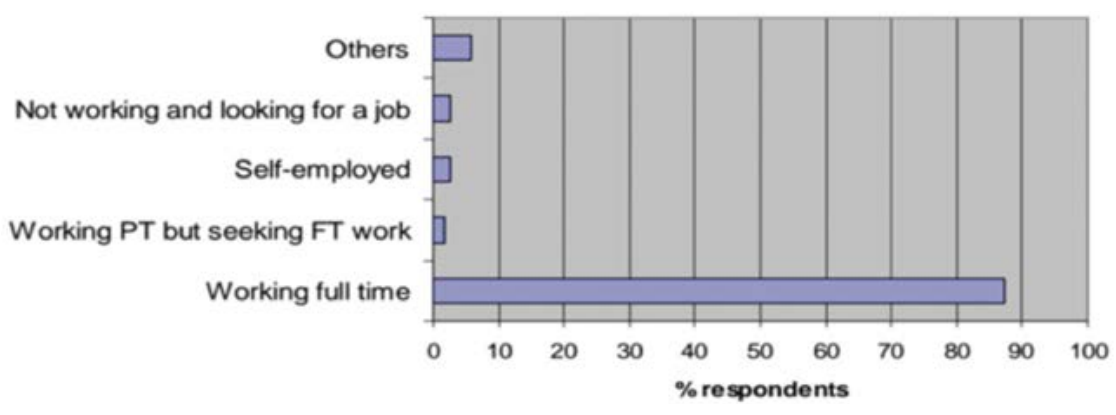

Figure 1

Employment status of FoA graduates in $2010^{27}$

Source: FoA Tracer Study, 2010.

More than 1 out of 2 respondents found a job within five months after graduation and only 1 out of 4 took more than 10 months to secure a job (Figure 2).

${ }^{26}$ Kamleshwar Boodhoo, Dayawatee Goburdhun, Sunita J. Santchurn and Arvind Ruggoo, "Faculty of Agriculture. Tracer study of graduates (2003-2007)." (2010). Edited by The Faculty of Agriculture, University of Mauritius, 4-5 (unp.).

27 Ibid. 


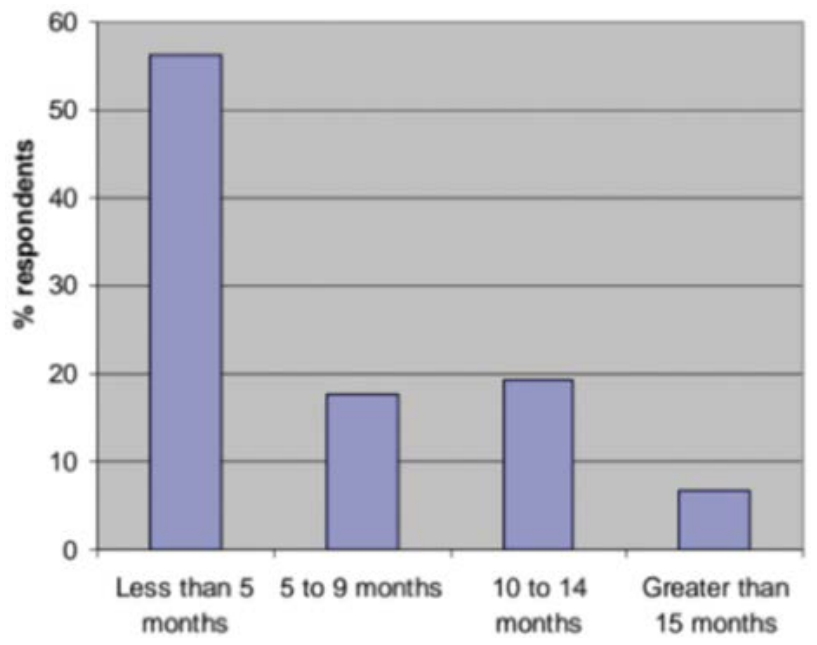

Figure 2

Time lag between graduation and first job

Source: FoA Tracer Study 2010.

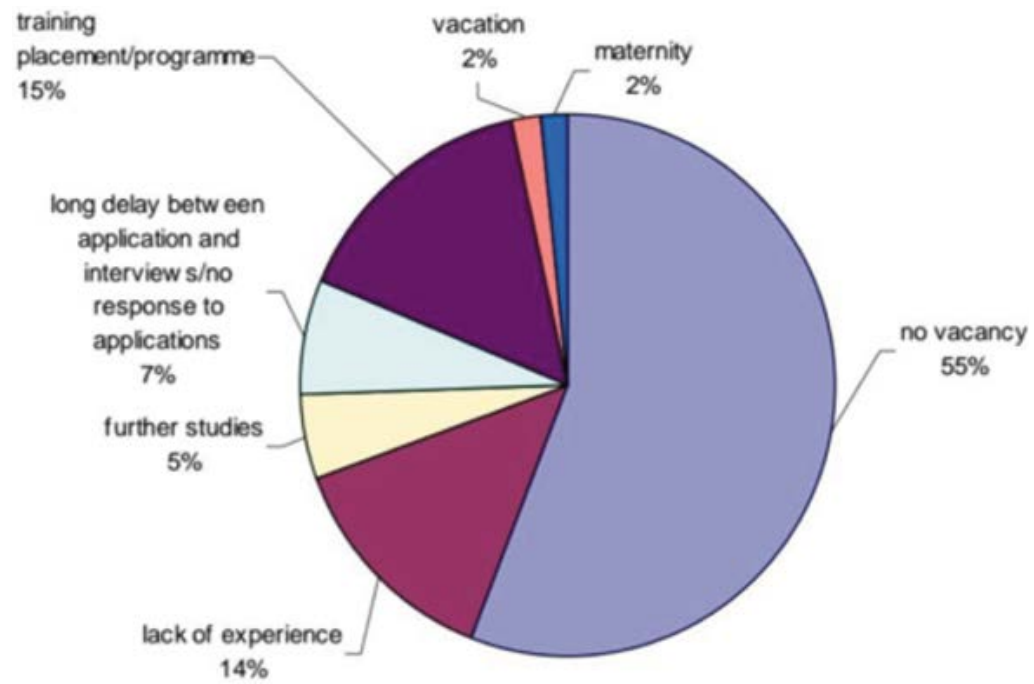

Figure 3

Reasons for time gap between graduation and first job 
The most frequent reason to explain the time gap between graduation and first job was the lack of vacancy in the field of Agriculture (Figure 3).

The results of this tracer study were useful to formulate questions for the survey of FoA alumni.

\section{Results}

\section{III.1. Quantitative results}

The results section has been divided into two main sections namely quantitative results from the different surveys carried out, and qualitative results from the analysis of on-site placement supervisors' evaluation forms.

III.1.1. Perceptions of current FoA students on their training at FoA and their employability skills

\section{III.1.1.1. General profile of students}

Out of the 80 respondents, there were $53.3 \%$ female students (43 female students). From the total respondents, $38.3 \%$ (31 students) of them were students who registered in 2013,23.3\% (18 students registered in 2014 and $38.3 \%$ (31 students registered in 2015).

\section{III.1.1.2. Satisfaction of the students with the course BA\&T}

The students were asked to rate their satisfaction level with the course BSc (Hons) Agriscience and Technology (BA\&T). From the survey, it was found that a majority of them $(56.7 \%$ - 45 out of 80 students $)$ was slightly satisfied with their course; $33.3 \%$ (27 students) of them were slightly dissatisfied and only $1.67 \%$ (13 students) of them were very dissatisfied.

\section{III.1.1.3. Perceptions of current students on their employability skills}

Current FoA students were surveyed on their perceptions of skills that they consider they have acquired during their training at FoA at different levels of study, that is, from year one to year three (Table 1). 
Table 1

Percentage of current FoA students who agree that they have achieved employability skills

\begin{tabular}{|l|c|}
\hline \multicolumn{1}{|c|}{ Employability skills } & $\begin{array}{c}\text { Percentage of current FoA students who agree } \\
\text { that they have achieved employability skills }\end{array}$ \\
\hline Team working skills & 61.7 \\
\hline Communication skills & 63.3 \\
\hline Writing and reporting skills & 46.7 \\
\hline Statistical analysis skills & 46.7 \\
\hline $\begin{array}{l}\text { Awareness of modern } \\
\text { technologies in Agriculture }\end{array}$ & 65.0 \\
\hline Management skills & 60.0 \\
\hline Practical (Laboratory) skills & 64.0 \\
\hline
\end{tabular}

A number of students $(35 \% ; 21$ out of 60 students) were of the view that the module content of the BA\&T course was not up-to-date with modern technologies in the agricultural sector. They proposed the following innovations to the course content:

- The addition of more modern machines and equipment in the FoA laboratories.

- Implementation of new structured modules in relation with the new technologies in the agricultural sector locally and internationally.

- The setting up of a new framework of study that will encompass innovative ways of teaching and learning.

- The addition of new modules that are in relation with the new Mauritian Agriculture strategic plan of 2015 such as organic farming.

- More focus on modules related to climate change and preparing student to contribute to the issue of climate change in the world.

- Increasing the number of hours concerning the modules related to hydroponics and greenhouses production systems.

- Increasing the amount of site visits to modern enterprise and companies where students will have knowledge in the production systems of modern Agriculture. 
- Some students feel that seminars related to their course of study and future career should be proposed so that they know what is happening in the job- market in the island and around the world.

\section{III.1.2. Perceptions of alumni of FoA on their training at FoA and employability skills}

\section{III.1.2.1. Employment profile of the FoA alumni who have followed a BA\&T course}

$59.3 \%$ ( 21 out of 35 alumni) of the respondents of the survey were male. The average age of all the respondents was about 27 years old. 86.2\% (30) of those alumni had completed an undergraduate course at the Faculty of Agriculture; $11.1 \%$ (39) had successfully completed a Post graduate; and $3.7 \%$ (1) had received a Diploma from the Faculty.

The results of the survey indicated that $70.4 \%$ (25) of graduates from the FoA had already secured a job, and were actually in employment. The rest could not manage to find a job.

About $36.07 \%$ (13) of respondents were employed in the Public sector, mainly the ministry of Agriculture and related departments. 26.2\% (9) of those alumni managed to find a job in the Private sector of Mauritius. It was also observed that about $14.75 \%$ (5) of alumni have created their own business and have become entrepreneurs. $11.18 \%$ (4) of those alumni have found a job at the Faculty of Agriculture as a Lecturer or a technical assistant. About 8.2\% (3) have changed their field of work, and are working in sectors such as information technology, health, and engineering amongst others.

$40 \%$ (14) of the alumni have secured a job only after one to three months. Some graduates (30\% - 11 alumni) have been employed for the first time after four to twelve months. $18 \%$ (6) of those graduates have found their first job after one to two years after their graduation. Only 6\% (2) of those students had the opportunity to engage themselves in their first job after one to four weeks after completing their course BA\&T at the FoA. 4\% (2) of those students found it really difficult to find a job; they secured their job only after two to five years after their course. It is to be noted that $2 \%$ (1) of those graduates already found a job before their graduation.

\section{III.1.2.2. Perceptions of FoA alumni on their employability skills}

The course BA\&T has its own curriculum framework from which, courses, lectures, field visits and other activities are organised. The curriculum framework 
contains as well all the learning outcomes and all the attributes that have to be grasped by the student upon completion of the course. During the survey, only $11.1 \%$ (4) of alumni agreed that they have grasped all the learning outcomes from their curriculum framework after the completion of their course.

It was found that a majority of the alumni had some trouble in the completion of their technical skills. Most of them specified that after completion of the course, they were not aware of and could not use modern technologies in the agricultural sector. The main skills which they have failed to master include management skills, problem solving skills, communication skills, leadership skills and the implementation of innovative ideas; as well as entrepreneurial skills.

Alumni were asked about the main skills and attributes that were required at the enterprise level and which were not completed by the course BA\&T. $13.3 \%$ (5) of alumni think that their IT skills were not well developed. $8.8 \%$ (3) feels that their communication and writing skills have not evolved properly and faced some problems at their workplace. About $4.4 \%$ (2) of those students were not well trained to work with other members of their enterprise due to the fact that they did not understand the interpersonal relationships with other employees.

The main attributes and skills that those alumni use at their workplace are their technical skills. The most important skills which students referred to was working under stress which were new to them. They also tend to have a greater sense of responsibility while working at their workplace that is either in laboratories, fields or enterprises.

After completion of their course at the FoA, a majority of 64\% (22) would recommend future students to undertake a course at the Faculty of Agriculture.

\section{III.1.3. Perceptions of employers on employability skills of FoA undergraduates}

A sample of employers, who usually employ undergraduates who have studied on the course BA\&T, were surveyed on the competences and skills that they have observed from their employees.

It was found that $31.9 \%$ (11) of the undergraduates were employed for their technical ability, $23.4 \%$ (8) have been given a managerial role at the enterprise; $23.4 \%$ (8) work as Health \& Safety officers; $17.02 \%$ (6) worked as researchers; $2.12 \%$ (1) of those graduates entered the human resource section; and $2.13 \%$ (1) were assigned other jobs such as maintenance officer, IT officer and some entered the engineering sector. 


\section{III.1.3.1. Satisfaction of Employers about employability skills of BA\&T-trained employees}

It was found that only $6.6 \%(<1$ employer) of the employers were very satisfied with the performance of their employees, that is, less than 1 out of 16 employers. $13.3 \%$ (2) of the employers were slightly dissatisfied with technical and laboratory skills of their recruited graduates. 53.3\% (9) of employers were slightly satisfied with the team working skills of their workers. About $40 \%$ (6) of the employers were slightly satisfied with the communication skills of their workers. Only $20.1 \%$ (3) of them were slightly satisfied with the writing skills of their workers. $6.6 \%$ (1) were very satisfied with the management skills and the research and innovative ideas of their employees. 33.3\% (5) of the employers were only slightly satisfied with the problem solving skills. Only $46.7 \%$ (7) of them were slightly satisfied with the statistical skill of their workers. $46.7 \%$ (7) were slightly satisfied with the awareness of their employees about modern technologies in Agriculture. 66.6\% (11) of them were slightly satisfied with the overall performance of their employees.

III.1.4. Perceptions of technical staff on employability skills of current FoA undergraduates

A total of 18 technicians from the FoA participated in the survey; 55.6\% (10 technicians) of them were male technicians. Students enrolled in the course BA\&T have practical laboratory classes during their three academic years until the completion of their course. Thus, all the technicians working in those laboratories are familiar with the students' performance and skills. From the survey, only $11.1 \%$ (2) of the technicians were satisfied with the technical skills of the students. 44\% (8) of the technicians agreed that students receive all the technical skills required to enter the job market.

The technicians proposed a few reasons for their poor evaluation of the technical skills of undergraduate students:

- They fail in grasping protocols; and experiments are not informed by a review of relevant literature.

- There are not enough on-site practical classes.

- They do not understand the principles of chemistry behind the experiments and practical classes.

- They receive only the basic training in Food science and Post harvesting, they will not be able to work in such enterprises. 
- They lack skills where IT can be used in the experiments, such as the use of GIS software in the soil sciences practical.

- They lack the use of modern technologies and equipment in the laboratories.

- They need more site visits in farms or enterprises where they can learn how experiments and analysis are done in the real world.

\section{III.2. Qualitative results}

This section present the analysis of the on-site supervisor's evaluation of the student work placement that usually takes place for 6-8 weeks at the end of the second year of the curriculum.

III.2.1. Evaluation of the students' employability skills by the on-site supervisor

On-site supervisors provided an assessment of the students on work placement as shown in Table 2.

Table 2

Employers' perceptions on undergraduates' skills and attributes

\begin{tabular}{|l|l|l|}
\hline \multicolumn{1}{|c|}{ Student's Personality } & \multicolumn{1}{|c|}{ Student's Quality } & \multicolumn{1}{c|}{ Drawbacks of Student } \\
\hline $\begin{array}{l}\text { Good adaptation in } \\
\text { company }\end{array}$ & Responsive & Poor Attendance \\
\hline Cooperative & Positive attitudes & Timid \\
\hline Attentive & Hardworking & Fright of other members \\
\hline Good team spirit & Willing to learn & Lack of Experience \\
\hline Disciplined & Enthusiastic & $\begin{array}{l}\text { More to learn in team } \\
\text { spirit }\end{array}$ \\
\hline Dedicated to work & Innovative Ideas & $\begin{array}{l}\text { Limited Ability in } \\
\text { conducting research }\end{array}$ \\
\hline Responsive & Fast-Learner & $\begin{array}{l}\text { Need too much } \\
\text { continual technical } \\
\text { report }\end{array}$ \\
\hline Available & Courteous & \begin{tabular}{l} 
Very shy \\
\hline
\end{tabular}
\end{tabular}




\begin{tabular}{|l|l|l|}
\hline \multicolumn{1}{|c|}{ Student's Personality } & \multicolumn{1}{|c|}{ Student's Quality } & \multicolumn{1}{c|}{ Drawbacks of Student } \\
\hline $\begin{array}{l}\text { Keen interest In work } \\
\text { assigned }\end{array}$ & Good Decision making & Lack of confidence \\
\hline Motivated students & Pro-active & \\
\hline & $\begin{array}{l}\text { Good Skills and } \\
\text { Knowledge }\end{array}$ & \\
\hline
\end{tabular}

Table 3 shows the assessment of the employability skills of the students on work placement by the on-site supervisor. Only the percentage marked excellent has been shown with the basis that this is the highest achievement from the perception of the employers. It can be observed that the lowest score has been given to written skills and the highest score to team working ability.

\section{Table 3}

Assessment of the employability skills of the students on work placement

\begin{tabular}{|l|c|}
\hline \multicolumn{1}{|c|}{$\begin{array}{c}\text { Employability skills demonstrated } \\
\text { by the students }\end{array}$} & $\begin{array}{c}\text { Percentage of students who scored } \\
\text { excellent for the employability skill }\end{array}$ \\
\hline Adherence to the organisation & 25.9 \\
\hline Oral communication & 12.1 \\
\hline Written skills & 8.6 \\
\hline Interpersonal relationship & 17.2 \\
\hline Enthusiasm at work & 19.3 \\
\hline Problem solving & 17.2 \\
\hline Working capacity & 17.5 \\
\hline Team work & 63.2 \\
\hline $\begin{array}{l}\text { Contribution to the activities of the } \\
\text { organisation }\end{array}$ & 15.8 \\
\hline
\end{tabular}

III.2.2. Ways to improve the students' employability on the work placement program

From the on-site supervisors' point of view, it is important that the students should know well in advance what they are expected to achieve in 
the work placement. In order to do so, it is important that the students document themselves well about the vision, the mandate and the objectives of the enterprise or workplace well-before coming for their placement. One of the striking point from the report states that the students should prepare their communication skills well before they start their placement program.

Many employers feel that the placement period is too short, that is the 6-8 weeks are not enough for the student to learn about the daily work at an enterprise. Most of them are willing to extend the placement period to a 6 month basis.

Employers are much in favour that the student's academic tutor from the FoA should come and assess the student at a regular basis so that they can see what is missing from the placement and how it can be improved.

The employers also note that more and more students are having problems to work in a laboratory because they are unaware of new equipment in labs and are not well up to date about new technologies in the agricultural sector.

This study, using the Tuning methodology, has contributed to the construct of a meta-profile for the subject of Agriculture (Table 4). The generic and subject-specific competences of graduates in Agriculture, expected to contribute to the development of Agriculture in the Republic of Mauritius and in the region are: (i) problem-solving, (ii) critical thinking, (iii) oral and written communication, (iv) practical (v) self-management and professional development, (vi) knowledge of new technologies in Agriculture, (vii) management, (viii) conduct research and contribute to innovation and economic growth.

\section{Conclusion}

The focus of this study was on the employability and employability skills of undergraduates for the job market. The study was applied in a specific context and discipline, namely undergraduates studying Agriculture at the Faculty of Agriculture of the University of Mauritius. The perceptions of different actors were sought namely current FoA students, alumni of FoA, current technicians working at FoA, and current and potential employers of FoA undergraduates.

From the study it was revealed that $56.7 \%$ of the students (45 students) were alumni slightly satisfied with the course BA\&T. However, some of the students feel they lack skills in: management (14.3\% -11 students), research and innovative ideas (13.9\% - 11 students) and other skills such as problem 
solving skills and communication skills. This reflects some of the findings of Robinson and Garton ${ }^{28}$ who carried out a study on the assessment of employability skills required by graduates in Agriculture; and the findings of Baharun and Suleiman ${ }^{29}$ on transferable skills of importance to graduates. In addition, Most of the students feel that they are not confident enough to embark on a training program at post-graduate level. This points out to a lack of self-confidence of the graduates who cannot make use of their acquired skills as a stepping stone to chart out their future autonomously. As put forward by Hodzic ${ }^{30}$ developing an entrepreneurial attitude in universitytrained future job seekers should be on the agenda of TEIs whereby graduates look for opportunities either in the job market or for further studies.

Although $80 \%$ (64) of the students interviewed feel that they have upgraded their practical skills during the course, they put forward that "limited time is allocated to complete practical sessions" and some stated that the laboratory standards were not comparable to laboratory facilities in a professional environment. This fact is more institution-specific and especially for publicfunded universities like the University of Mauritius whereby access to funding are limited hence restricting the modernisation of laboratory facilities.

Many students who go on work placement during their course face difficulties with respect to their report writing skills. Indeed, generic skills as reported by Selvadurai ${ }^{31}$ have found their way in university curricula as a way of promoting graduates employability. From the report, it was also found that the students should improve their communication skills and other attributes related with socialising with other employers and members in the workplace. It was also stated that for students undertaking a placement in enterprises, where field work is a must, those students should be more prepared to work under the conditions. A question that remains though, as stated by Archer and Davison, ${ }^{32}$ although universities may provide, within their curriculum, opportunities for students to develop their soft skills, to

${ }^{28}$ Shane J Robinson and Bryan L Garton, “An assessment of the Employability skills needed by graduates in the college of Agriculture, food and natural resources at the university of Missouri," Journal of Agricultural Education 49(4) (2008): 96-105.

${ }^{29}$ Rohaizat Baharun and Ebi Shahrin Suleiman, "The employers' perceptions of what makes graduates marketable," Academia.edu 1-17 (2009).

${ }^{30}$ Sabina Hodzic, "Increasing PhD students' employability by focusing on the academic entrepreneurship. The analysis of entrepreneurial competences," Tuning Journal for Higher Education 3, no. 2 (2016): 347-387.

${ }^{31}$ Sivapalan Selvadurai, Er Ah-Choy, and Marlyna Marosi, "Generic skills of prospective graduates from the employers' perspectives,” Asian Social Science 8, no. 12 (2012): 295-303.

${ }^{32}$ Will Archer and Jess Davison, "Graduate employability. What do employers think and want. The Council for Industry and Higher Education, UK," (2008). 
what extent students are willing to 'take-up' those skills? The important role of career advisory services on university campus is therefore highlighted here both for pre-and post-graduation students.

About $35 \%$ of students (28 students) feel that the course is still oriented towards current traditional agricultural production systems and is not in line with the Mauritian agricultural strategic plan (2016-2020) which lay emphasis on the production of high quality strategic commodities to satisfy local demand and reduce the dependence of the country on importation. This percentage represents about one-third of the respondents and points out indirectly to the inability of those students to become autonomous learners and to be proactive and adaptable to the job market and learn about new techniques independently. This is certainly a skill that needs to be developed at the level of students as mentioned by Tomlinson ${ }^{33}$ whereby he talks of the transition from higher education to the labour market as being an active process for graduates and that the latter should be able to develop labour market strategies to increase their employability. As Harvey ${ }^{34}$ stated, a degree is no more a "passport into graduate employment", it does not guarantee a job or a career and should be seen by the graduate as a stepping stone in the recruitment process.

The results have showed that $70.4 \%$ (25) of the alumni managed to find a job either in the public (36.1\% -13 alumni) or private sector $(26.03 \%-9$ alumni) of Mauritius. From the study it was found that $40 \%$ (14) of them were employed only one to three months after their graduation. From the FoA Tracer study 2010, it was found that about $55.6 \%$ (221) of the graduates were employed after one to three months, this shows that it is becoming more difficult to find a job in the agricultural sector in Mauritius. However, as Brown ${ }^{35}$ have pointed out, it is difficult to directly relate unemployment to unemployability as there may other external factors such as political and economic environment that may not be conducive for job seekers.

After the completion of their degree, 63\% (22) of the alumni agreed that they have grasped all the learning outcomes of the course. There were; however some students who stated that "I have completed my degree only for the sake to pass my exam, but at the end of the day, only small amounts of learning outcomes were grasped." The major learning outcomes and skills they feel that they have not completed are the practical technical skills

${ }^{33}$ Michael Tomlinson, "Graduate employability and student attitudes and orientations to the labour market," Journal of Education and Work 20, no. 4 (2007): 285-304.

${ }^{34}$ Lee Harvey, "New realities: the relationship between higher education and employment," Tertiary Education and Management 6 (2000): 3-17.

${ }_{35}$ Phillip Brown, Anthony Hesketh, and Sara William, "Employability in a knowledgedriven economy," Journal of Education and Work 16, no. 2 (2003): 107-126. 
(27.5\% - 10 alumni). However, $15.1 \%$ (5) of alumni feel that they have not grasped any outcomes related to the modern technologies in the agricultural sector; this point is a major leitmotiv from the different categories of students (current and alumni). These issues point again to the importance of continuously bringing the student from his/her first year at university in relation to the professional world so that he/she realises the expectations of potential employers and are not left to face the consequences post-graduation.

The major skill identified by alumni as being very important in their workplace is technical skill. The fact that $27.5 \%$ (10 alumni) of them felt they have not achieved good technical skills shows that some alumni had some struggle to adapt themselves at the workplace. In spite of drawbacks, a majority of $64.0 \%$ (22) of alumni would recommend future tertiary students to enroll on the BA\&T course. Some students stated that "There is no job prospect and I had to change my career path." Developing graduates' attitudes and labour market strategies should be encouraged in TEIs and reinforced through regular interactions with the professional world through internships, site-visits, seminars involving employers' participation amongst others ${ }^{36}$.

Most of the undergraduates from the BA\&T course were employed as Technical staffs $(31.9 \%-11$ alumni). From the employer's perspectives $60.1 \%$ ( 10 employers) of them were satisfied with the overall performance of the graduates. Employers seem to appreciate the theoretical level of the students, and their team working ability. Some state that "the students are really pro-active and they have the zeal to work, (...) they are hard workers". However, most of the employers are not satisfied with the technical skills, communication skills and the writing skills of their employees. The emphasis placed by employers on soft skills is very much present in the literature. A study by Archer and Davison ${ }^{37}$ on employers' perceptions and wants regarding graduate employability confirmed that more than $85 \%$ of employers regard soft skills as more important than degree qualification. The top three rated skills and qualities sought after by employers include (a) communication skills, (b) team-working skills and (c) integrity. The evaluation by technical staff of FoA on the technical skills of students was quite revealing. 55.6\% (10) of the technicians feel that their laboratories are not up to date with modern laboratories. For instance, students have problems in preparing chemical solutions; they have difficulties in the implementation of practical

${ }^{36}$ Kevin Lowden, Stuart Hall, Dely Elliott, and Jon Lewin, "Employers' perceptions of the employability skills of new graduates" (Research commissioned by the Edge Foundation. SRCE Centre, University of Glasgow, 2011).

37 Will Archer and Jess Davison. "Graduate employability. What do employers think and want. The Council for Industry and Higher Education, UK" (2008). 
sessions on the UoM farm; and some of them lack concentration and thus lack interest in laboratory practicals. About $55.6 \%$ (10 technicians) of them do not agree with the fact that the student receives all the technical skills required to enter the job market. Thus, the fact that employers are dissatisfied with the technical skills of their employees is justified. The general rating on technical skill that technical staffs attribute to the actual students is 5 out 10 .

Employers, in this present study, also specify that graduates are not up to date with the modern technologies in the agricultural sector around the world. $13.3 \%$ (2) of the employers are very dissatisfied with the ability of their employees to work with modern technologies, some stated: "My employees were thought only about the traditional ways of cultivation of crops at the university; they have to be further trained to adapt themselves with new technologies nowadays." A question that can be asked here is whether it is fair for TEIs to produce oven-ready graduates that can be a perfect-fit for the job market? As Atkins ${ }^{38}$ put forward, if all students had the same portfolio of employability skills, their comparative market advantage would disappear. The same author also talks about 'graduateness' and query the fact whether a student should be denied graduation if he or she did not attain the minimum threshold in core and generic skills in the same way as graduation is usually denied for empirical evidence of non-mastery of subject and discipline-specific skills.

According to this study, there seems to be a mismatch between what employers in the agricultural sector expect from their employees and what undergraduates from the FoA can provide in terms of skills and attributes. The focus of employers on undergraduates having very good technical skills is very high and should be addressed by the FoA in terms of upgrading of its laboratory facilities. Even though in a context of economic crisis, major investments may not be possible in the short term, other strategies can be envisaged such as establishing partnerships with employers so that students, during their studies at the University of Mauritius, can be trained in professional and modern laboratories in the public and private sectors for the benefit of all parties concerned. As put forward by CBI/Pearson,,$^{39}$ addressing employability skills shortcomings of graduates is best done in partnership with the students, the employers and the Tertiary Education Institutions.

The findings of this study point to the fact that the FoA should find new ways of teaching agricultural sciences, where the students will achieve all the

${ }^{38}$ M J Atkins, "Oven-ready and self-basting: taking stock of employability skills," Teaching in Higher Education 4, no. 2 (1999): 267-280, doi:10.1080/1356251990040208.

${ }^{39} \mathrm{CBI} /$ Pearson, "Learning to grow: what employers need from education and skills" in Education and Skills Survey (2012), www.cbi.org.uk. 
required skills and attributes to boost up their employability skills. The creation of a new framework and structure of programs will help future students to be more skillful and will be up to date with the modern activities in Agriculture prevailing in Mauritius. A curriculum map should be developed to addresses graduate attributes and learning outcomes, as they relate to professional competencies. The task of this new framework will be to upgrade and modernise the value addition that the future graduates profile will require. The employability of graduates should be the main issue and objectives before the creation of new programs at the University level, to promote the employability of the students, the program should be more focused on the approaches to placements, work based learning and internships. This should be implemented for a significant duration. Hence, this study proposed an enhanced curriculum map (Annex A-Table 4) for the course BA\&T that could be used for the development of a new curriculum framework. The new course will help in boosting up the employability of the graduates and improve the profile of the graduates.

Contributing to the enhancement of employability skills of undergraduates from FoA is important for the country. The actual unemployment rate in Mauritius ${ }^{40}$ is about $8.70 \%$, and if this continues to increase, it will affect the growth of the Mauritian economy. Each year about 50-70 students complete their undergraduate studies in Agriculture. Those graduates face a lot of difficulties in achieving their first job. With this high rate of unemployment, the Mauritian government has to invest on them, by providing incentives and other employment schemes to keep them in the society. The social expenses of unemployment are hard to compute, but no less real. ${ }^{41}$ The employability of the graduates, if not addressed by all stakeholders, will become a pervasive problem. It will affect not only the students' self-confidence but will also affect the whole Mauritian society. The strategic plan 2016-2020 for the agricultural will only be a myth if no remedies are found in the near future to ensure that the adequate workforce is being trained to operationalise and sustain these strategies which aim at ensuring food security for the Mauritians. However, it should also be noted that as in all dynamic economies, job markets can become congested at some point and as rightly stated by Brown ${ }^{42}$ in a knowledgedriven economy, graduates may be employable but not in employment.

40 "Statistics Mauritius," Ministry of Finance and Economic Development (2015). http:// statsmauritius.govmu.org/English/StatsbySubj/Documents/Digest/Digest $\% 20$ of $\% 20$ Agricultural\%20Statistics\%202014.pdf.

${ }^{41}$ Stephen Simpson, "How unemployment rates affects the economy," Elite Daily 1 (2011): 2, http://elitedaily.com/news/business/how-unemployment-rates-affect-the economy/.

${ }^{42}$ Phillip Brown, Anthony Hesketh, and Sara William, "Employability in a knowledgedriven economy," Journal of Education and Work 16, no. 2 (2003):107-126. 
The present study has its limitations as it is confined to a small sample, and is based on one discipline only and in a specific context. It is therefore not within the scope of this study to compare findings with more developed economies. This does not, however, preclude future investigations as discussed hereafter. This study aims at contributing to the debate on employability and employability skills of university graduates and the need to have a more structured and harmonised approach with the involvement of all stakeholders' concern. An analogy can be made to the concept of a value chain in the agrifood sector whereby all actors involved in the value chain need to develop mechanisms to work together so as to increase the efficiency of the chain at all levels from production (of graduates) to consumption (by employers in the workplace). There are elements of trust and governance that also come into play to ensure that whatever is produced in that value chain abides to the norms and standards of the society. Who will be the governor or main driver in the chain? Will that be a demand-driven chain whereby it is the job market that imposes the types of graduates they want? Supporting public and private institutions also play a major role in ensuring the proper functioning of the value chain. In the same way, higher education institutions are providers of education and training in the majority of disciplines that are sought after in the job market; and employers are the final consumers. If there is a weak link in the chain, it is of national interest to strengthen that link for the betterment of society at large. As proposed by Alshamy, ${ }^{43}$ "all stakeholders including academics, students, graduates, potential employers and professional organizations should be indirectly involved at different stages in the process of curriculum design and quality enhancement." Selvadurai ${ }^{44}$ also proposed in their study in the Malaysian context, that future studies should look at ways and means whereby employers can help in transferring skills to university trainees as part of stakeholders' involvement in the development of tertiary curriculum. There are a lot of scope for further studies whereby all the employable skills identified both by the TEIs and the employers can be strengthened as part of a partnership, and looking for new alternatives for each of the drawbacks that may be identified. Figure 4 (Annex B) proposes a model of the dynamic partnership that should exist between stakeholders in the higher education sector. There should be a discussion with the different stakeholders of the sector, and create a new curriculum framework which reflect the needs of the job market. Even though

${ }^{43}$ Alsaeed Alshamy, "Teacher education programmes at Alexandria University with reference to Tuning Methodology," Tuning Journal for Higher Education 3, no. 2 (2016): 281-317.

${ }^{44}$ Sivapalan Selvadurai, Er Ah-Choy, and Marlyna Marosi, "Generic skills of prospective graduates from the employers' perspectives,” Asian Social Science 8, no. 12 (2012): 295-303. 
in some context, employability may not be a panacea for unemployment ${ }^{45}$, ${ }^{46}$, in emerging economies like Mauritius, it is important to have a clear and harmonised tertiary education policy which englobes all stakeholders concerned.

The results from this study have revealed some very interesting facts about how current students perceive their employable skills and the difference in perception for past (alumni) students. The expectations of employers have also shed light on what is currently taught in the BA\&T course at FoA and what employers actually look for. There are discrepancies indeed between different stakeholders' perspectives; however, the aim is to come to a consensus on the way forward for the benefit of all concerned and the benefit of the country at large.

\section{Bibliography}

Alshamy, Alsaeed. "Teacher education programmes at Alexandria University with reference to Tuning Methodology." Tuning Journal for Higher Education 3, no. 2 (2016): 281-317.

Archer, Will, and Davison Jess. "Graduate employability. What do employers think and want. The Council for Industry and Higher Education, UK." 2008.

Atkins M J. "Oven-ready and self-basting: taking stock of employability skills." Teaching in Higher Education 4, no. 2 (1999): 267-280. doi:10.1080/1356251990040208.

Baharun, Rohaizat, and Suleiman Ebi Shahrin. "The employers' perceptions of what makes graduates marketable.” Academia.edu 1-17 (2009).

Boodhoo, Kamleshwar, Goburdhun, Dayawatee, Santchurn, J. Sunita, and Ruggo, Arvind. "Faculty of Agriculture. Tracer study of graduates (2003-2007)." (2010). Edited by The Faculty of Agriculture, University of Mauritius, 4-5 (unp.).

Brown, Phillip, Hesketh Anthony, and William Sara. "Employability in a knowledgedriven economy." Journal of Education and Work 16, no. 2 (2003): 107-126.

CBI/Pearson. "Learning to grow: what employers need from education and skills." Education and Skills Survey. 2012. www.cbi.org.uk.

Central Statistics Office (Mauritius). "Mauritius in Figures.” Ministry of Finance and Economic Development. http://statsmauritius.govmu.org/English/Publications/ Documents/MIF/mif09.pdf.

Dinan, Pierre. "The agricultural sector in Mauritius: Economic aspects-Past, present and future." Presented at the Symposium on Agriculture in Mauritius: Evolution and Prospects on 29th October 2003. Mauritius Chamber of Agriculture. 2003. www.mchagric.org/images/pdf/p_dinan.pdf.

${ }^{45}$ Nick Wilton, "Business graduates and management jobs: an employability match made in heaven?" Journal of Education and Work 21, no. 2 (2008): 143-158.

${ }^{46}$ Nick Wilton, "Do employability skills really matter in the graduate labour market? The case of business and management graduates," Work, Employment and Society 25, no. 1 (2011): 85-100. 
Harvey, Lee. "New realities: the relationship between higher education and employment." Tertiary Education and Management 6 (2000): 3-17.

Hillage, Jim, and Pollard Emma. "Employability: developing a framework for policy analysis." Research Brief No. 85. London: Department for Education and Employment, 1998.

Hodzic Sabina. "Increasing PhD students' employability by focusing on the academic entrepreneurship. The analysis of entrepreneurial competences." Tuning Journal for Higher Education 3, no. 2 (2016): 347-387.

Lees, Dawn. “Graduate Employability - Literature Review.” LTSN Generic Centre. University of Exeter, 2002. http://www.palatine.ac.uk/files/emp/1233.pdf.

Lowden, Kevin, Hall Stuart, Elliot Dely, and Lewin Jon. 'Employers' perceptions of the employability skills of new graduates." Research commissioned by the Edge Foundation. SRCE Centre, University of Glasgow, 2011.

Murray, John. "A Gap Analysis Process to improve IT management." In The gap Analysis Process; Practical Example; Process Goals and Hurdles; Process Mechanics. 2000. Auerbach Publications. CRC Press LLC. http://www.ittoday. info/AIMS/Information_Management/1-04-35.pdf.

OECD. "Tertiary Education for the Knowledge Society: OECD Thematic Review of Tertiary Education: Synthesis Report.” 2008. Accessed August 11, 2016. http:// oecd-conference-teks.iscte.pt/downloads/OECD_overview.pdf.

Robinson, J Shane, and Garton Bryan L. "An assessment of the Employability skills needed by graduates in the college of Agriculture, food and natural resources at the university of Missouri." Journal of Agricultural Education 49(4) (2008): 96-105.

Rothwell, Andrew, Jewell Steven, and Hardie Marie. "Self-perceived employability: investigating the responses of post-graduate students." Journal of Vocational Behavior 75 (2009): 152-161.

Selvadurai, Sivapalan, Ah-Choy Er, and Marosi Marlyna. "Generic skills of prospective graduates from the employers' perspectives." Asian Social Science 8, no. 12 (2012): 295-303.

Simpson Stephen. "How unemployment rates affects the economy." Elite Daily 1, no. 2 (2011). http://elitedaily.com/news/business/how-unemployment-ratesaffect-the economy/.

Statistics Mauritius. Ministry of Finance and Economic Development, 2015. http:// statsmauritius.govmu.org/English/StatsbySubj/Documents/Digest/Digest\%20 of\%20Agricultural\%20Statistics\%202014.pdf.

Stwine, Elinor Edvardsson, and Alves Mariana Gaio. "Higher Education and employability of graduates: will Bologna make a difference?" European Educational Research Journal 9, no. 1 (2010): 32-44.

Tomlinson, Michael. "Graduate employability and student attitudes and orientations to the labour market." Journal of Education and Work 20, no. 4 (2007): 285-304.

UNESCO. "The 2015 Global Monitoring Report - Education for All 2000-2015: Achievements and Challenges." 2015. http://unesdoc.unesco.org/images/0023/ 002322/232205e.pdf. 
Wagenaar, Robert. "Competences and learning outcomes: a panacea for understanding the (new) role of Higher Education." Tuning Journal for Higher Education 1, no. 2 (2014): 279-302.

Wilton, Nick. "Business graduates and management jobs: an employability match made in heaven?" Journal of Education and Work 21(2) (2008): 143-158.

—. "Do employability skills really matter in the graduate labour market? The case of business and management graduates." Work, Employment and Society 25, no. 1 (2011): 85-100.

World Bank. "Education, Quality and Economic Growth.” 2007. http://siteresources. worldbank.org/EDUCATION/Resources/278200-1099079877269/5476641099079934475/Edu_Quality_Economic_Growth.pdf.

\section{About the Authors}

NIGEL YOVEN ARMOOGUM (nigel.armoogum@umail.uom.ac.mu) is a graduate from the Faculty of Agriculture (FoA) of the University of Mauritius. He has completed a degree in BSc (Hons.) Agriscience and Technology, University of Mauritius, Mauritius. He is a former FoA Representative where he contributed to the students' life at the University. His undergraduate dissertation work was on the competences and skills that are required by the graduates of his Faculty to match the expectations of employers in terms of employability of young and fresh graduates. During his time at the FoA, he organised several talks and campaigns for the protection of the fauna and flora of Mauritius. He mentors freshers on how they can improve the delivery of knowledge and how they can boost up their skills and competences. He was on student placement at the National Plant Protection Office of the Ministry of Agro-Industry and Food Security where he worked to help in the proper export and import of agricultural commodities and also at the port and airport to make sure that all the phytosanitary measures during trading is respected. He plans to undertake a Masters in Agricultural Sciences and continue his $\mathrm{PhD}$ in sustainable Agriculture.

BRINDA RAMASAWMY (b.ramasawmy@uom.ac.mu) is a lecturer in the area of agricultural economics and management in the Department of Agricultural Production and Systems at the Faculty of Agriculture, University of Mauritius. She holds a PhD in Management Sciences (Sciences de Gestion) from Montpellier Sup Agro, France. Her field of research includes agricultural entrepreneurship, agribusiness, agri-food value chain analysis, agricultural marketing and consumer behaviour. She has a keen interest in competence-based learning with the main aim of enhancing the employability of graduates from the Faculty of Agriculture to be in line with the demands of the job market and the needs of the Mauritian economy. She is currently coordinating, at the level of the University of Mauritius, an EU-funded Intra-ACP mobility projects which aims at harmonising the teaching of agribusiness across universities in the African continent. She also actively creates a bridge between the Faculty of Agriculture 
and stakeholders in the public and private sector so that students can benefit from targeted industrial placements with the possibility of conducting their dissertation work in collaboration with the industry. She firmly believes in a student-centred pedagogical approach.

BRIGITTE MARIE FRANÇOISE DRIVER (mfdriver@uom.ac.mu) is an Associate Professor at the Faculty of Agriculture, University of Mauritius. She has a PhD (Animal Science; Massey University, New Zealand). She is a Senior African Research Fulbright Fellow. She undertakes research and teaching in basic and applied animal science and production. Her primary research areas involve: basic and applied ruminant nutrition, forage feeding value and the development of sustainable grazing systems; management of sustainable tropical animal production systems; safe food production of animal origin; innovative feed supplies for livestock production. Her research aims at improving the profitability of animal production systems in Mauritius. She has over 40 peer-reviewed papers, 4 book chapters, and is the co-editor of 2 books. She has supervised MSc and $\mathrm{PhD}$ students.

\section{Annexes}

A) Curriculum Mapping for BSc (Hons) Agriscience and Technology (BA\&T)

Table 4

Curriculum Mapping ${ }^{47}$ for BSc (Hons) Agriscience and Technology (BA\&T)

\begin{tabular}{|l|l|l|}
\hline Graduates Attributes & \multicolumn{1}{|c|}{ Professional Competencies } & $\begin{array}{l}\text { A graduate of the course } \\
\text { BA\&T should be able to }\end{array}$ \\
\hline $\begin{array}{l}\text { 1. Ability to } \\
\text { embark on training } \\
\text { program at } \\
\text { postgraduate level }\end{array}$ & $\begin{array}{l}\text { The student will have } \\
\text { to apply their theories } \\
\text { and practical modules } \\
\text { acquired during the course } \\
\text { and reproduce them in } \\
\text { the workplace. Adapt } \\
\text { effectively to changes. } \\
\text { Take responsibility for } \\
\text { their own development. } \\
\text { Use their critical thinking } \\
\text { to evaluate assumptions } \\
\end{array}$ & $\begin{array}{l}\text { 1.1. Take responsibility } \\
\text { for their own professional } \\
\text { development and } \\
\text { learning to work in a new } \\
\text { environment } \\
\text { 1.2. Work for about } 6 \\
\text { months in a placement, } \\
\text { and adhere to the rules } \\
\text { and regulations of the } \\
\text { enterprise. } \\
1.3 . \text { To complete all } \\
\text { assigned work in a } \\
\text { professional manner. }\end{array}$ \\
\hline
\end{tabular}

${ }^{47}$ Source: Kevin Lowden, Stuart Hall, Dely Elliott, and Jon Lewin, "Employers' perceptions of the employability skills of new graduates," Research commissioned by the Edge Foundation. SRCE Centre, University of Glasgow (2011). 


\begin{tabular}{|c|c|c|}
\hline Graduates Attributes & Professional Competencies & $\begin{array}{l}\text { A graduate of the course } \\
\text { BA\&T should be able to }\end{array}$ \\
\hline & & $\begin{array}{l}\text { 1.4. Prepare a good and } \\
\text { focused placement report } \\
\text { that would englobe all the } \\
\text { task accomplished at the } \\
\text { enterprise } \\
\text { 1.5. Demonstrate } \\
\text { independence and } \\
\text { leadership }\end{array}$ \\
\hline $\begin{array}{l}\text { 2. Up-to-date } \\
\text { to modern } \\
\text { technologies }\end{array}$ & $\begin{array}{l}\text { Learn to use new } \\
\text { technologies; Recognise } \\
\text { their benefits and } \\
\text { limitations; to know when } \\
\text { to use the new technologies } \\
\text { to avoid any issue to the } \\
\text { environment in regard to } \\
\text { the climate change }\end{array}$ & $\begin{array}{l}\text { 2.1. Use the new and } \\
\text { existing technologies } \\
\text { relevant to their studies. } \\
\text { 2.2. Apply their } \\
\text { theoretical knowledge in } \\
\text { the application of these } \\
\text { new technologies }\end{array}$ \\
\hline $\begin{array}{l}\text { 3. Management } \\
\text { skills }\end{array}$ & $\begin{array}{l}\text { Recognise all the } \\
\text { various sectors related } \\
\text { to management in } \\
\text { Agriculture, the setting } \\
\text { up a business plan, } \\
\text { the implementation } \\
\text { of entrepreneurship } \\
\text { structures and the } \\
\text { development of new } \\
\text { management programs. }\end{array}$ & $\begin{array}{l}\text { 3.1. To be able to } \\
\text { develop a business plan } \\
\text { and an entrepreneurship } \\
\text { structure. } \\
\text { 3.2. To relate any } \\
\text { management skills with } \\
\text { their assignments, thesis } \\
\text { and dissertation }\end{array}$ \\
\hline $\begin{array}{l}\text { 4. Research and } \\
\text { Innovative Ideas }\end{array}$ & $\begin{array}{l}\text { Work independently to } \\
\text { produce good innovative } \\
\text { ideas in the construction } \\
\text { of assignments; Boost up } \\
\text { their research level to find } \\
\text { innovative ideas. Think } \\
\text { globally. }\end{array}$ & $\begin{array}{l}\text { 4.1. To develop new ideas } \\
\text { and propose then in their } \\
\text { assignment or thesis, } \\
\text { the student will be more } \\
\text { critical. }\end{array}$ \\
\hline $\begin{array}{l}\text { 5. Problem Solving } \\
\text { Skills }\end{array}$ & $\begin{array}{l}\text { Analyse a problem and try } \\
\text { to find the best possible } \\
\text { solution to alleviate the } \\
\text { problem or use their } \\
\text { critical thinking to resolve } \\
\text { them }\end{array}$ & $\begin{array}{l}\text { 5.1. To find problems and } \\
\text { to analyse them } \\
\text { 5.2. To find solution to } \\
\text { solve problems in either } \\
\text { theoretical issues or } \\
\text { practical issues } \\
\text { 5.3. To come up with } \\
\text { innovative solution that } \\
\text { will resolve all the issues }\end{array}$ \\
\hline
\end{tabular}




\begin{tabular}{|c|c|c|}
\hline Graduates Attributes & Professional Competencies & $\begin{array}{l}\text { A graduate of the course } \\
\text { BA\&T should be able to }\end{array}$ \\
\hline $\begin{array}{l}\text { 6. Communication/ } \\
\text { Oral Skills }\end{array}$ & $\begin{array}{l}\text { Exchange of information } \\
\text { with colleagues; have } \\
\text { appropriate inter-personal } \\
\text { skills; facilitate conflicts; } \\
\text { persuasively argue for the } \\
\text { right of the worker }\end{array}$ & $\begin{array}{l}\text { 6.1. Communicate at } \\
\text { an advanced level with } \\
\text { individuals and groups } \\
\text { and advocate for the } \\
\text { improvement of graduate } \\
\text { profile }\end{array}$ \\
\hline $\begin{array}{l}\text { 7. Technical/ } \\
\text { Laboratory skills }\end{array}$ & $\begin{array}{l}\text { Apply the logical and } \\
\text { rational behind the } \\
\text { practical work; understand } \\
\text { the chemistry behind the } \\
\text { practical work, use modern } \\
\text { apparatus for their } \\
\text { practical work }\end{array}$ & $\begin{array}{l}\text { 7.1. To apply their theory } \\
\text { in the technical work } \\
\text { 7.2. Will be able to } \\
\text { understand the chemistry } \\
\text { behind all practical work } \\
\text { 7.3. To find solutions to } \\
\text { improve their laboratory } \\
\text { skills }\end{array}$ \\
\hline $\begin{array}{l}\text { 8. Writing skills/ } \\
\text { Report skills }\end{array}$ & $\begin{array}{l}\text { To write in scientific } \\
\text { language and understand } \\
\text { the plagiarism concept; the } \\
\text { use of good referencing } \\
\text { in reports, thesis; develop } \\
\text { good practical reports and } \\
\text { the good mounting up of } \\
\text { thesis. }\end{array}$ & $\begin{array}{l}\text { 8.1. To write in a scientific } \\
\text { way and to implement } \\
\text { good referencing in } \\
\text { reports, assignments and } \\
\text { thesis } \\
\text { 8.2. To write in a good } \\
\text { scientific structured way }\end{array}$ \\
\hline $\begin{array}{l}\text { 9. Theoretical } \\
\text { Understanding }\end{array}$ & $\begin{array}{l}\text { Use of logic and } \\
\text { critical thinking for the } \\
\text { understanding of the } \\
\text { theory part of the module; } \\
\text { being able to grasp all } \\
\text { necessary data; Apply } \\
\text { all theoretical data to } \\
\text { practical work or during } \\
\text { placement programs }\end{array}$ & $\begin{array}{l}\text { 9.1. Use their theoretical } \\
\text { knowledge in practical } \\
\text { work, internships and in } \\
\text { the scientific writing of } \\
\text { thesis or assignments. } \\
\text { 9.2. Application of } \\
\text { knowledge in placement } \\
\text { programs } \\
\text { 9.3. Propose new ideas, } \\
\text { using their critical } \\
\text { knowledge and their } \\
\text { theoretical knowledge }\end{array}$ \\
\hline $\begin{array}{l}\text { 10. Team Working } \\
\text { skills }\end{array}$ & $\begin{array}{l}\text { Ability to work in a group } \\
\text { of colleagues and to } \\
\text { work efficiently; Propose } \\
\text { and discuss information } \\
\text { with other members of } \\
\text { enterprise; Recognise } \\
\text { individual and collective } \\
\text { human rights; respect other } \\
\text { members point of view }\end{array}$ & $\begin{array}{l}\text { 10.1. Ability to join } \\
\text { an enterprise and } \\
\text { communicate with respect } \\
\text { with other colleagues } \\
\text { 10.2. To work efficiently in } \\
\text { group projects }\end{array}$ \\
\hline
\end{tabular}


B) Dynamic model for stakeholders in the Higher Education sector

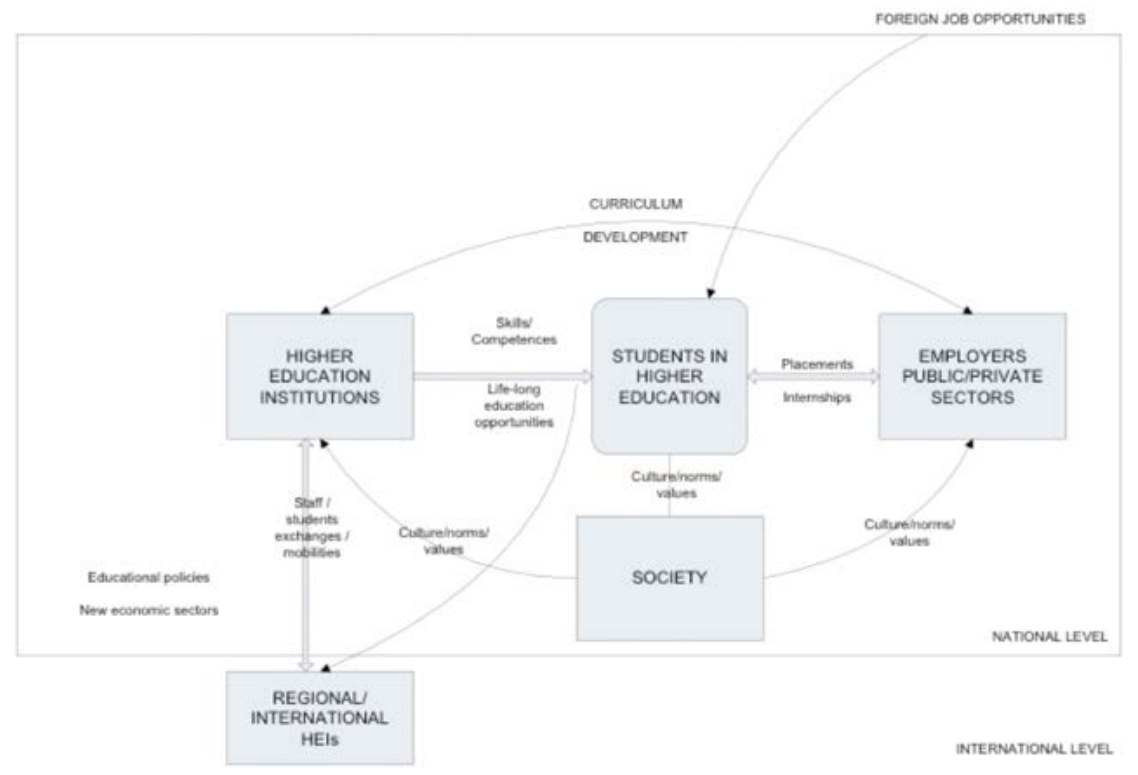

Figure 4

Dynamic model of stakeholders in the Higher Education Sector

Source: Authors.

C) Survey questionnaire for current FoA students

\section{UNIVERSITY OF MAURITIUS FACULTY OF ACRICULTURE}

Dear Students,

I am XXX, currently enrolled as full-time BSc student at the Faculty of Agriculture, University of Mauritius. In this respect, I am doing a survey on "Analysis on Actual students of BSc (Hons) Agriscience \& Technology" so as to propose an innovative curriculum framework for the teaching of Agriculture sciences. I seek your valuable opinion in this research study. Your response will be of great help for this study. Note that the data collected will remain strictly confidential. Thank you for your assistance in my educational endeavours. 


\section{SECTION A - DEMOGRAPHIC INFORMATION}

1. Gender

$\square$ Male $\square$ Female

2. During which year have you joined the Faculty of Agriculture?

$\begin{array}{ll}\square 2012 & \square 2014 \\ \square 2013 & \square 2015\end{array}$

3. Are you enrolled in the course BSc (Hons) Agriscience \& Technology?
Yes
$\square$ No
$\square$ No, but related to it

4. Are you generally satisfied with the course BSc(Hons) Agriscience \& Technology?

$\square$ Very Dissatisfied

$\checkmark$ Slightly Dissatisfied

$\square$ Neither Dissatisfied nor Satisfied

Slightly Satisfied

Very Satisfied

\section{SECTION B}

According to the BSc (Hons) program of study, upon completion of the course, the graduate should have grasped all the learning outcomes as per his/her course. These are the main skills and Competences you should have grasped:

- Theoretical Understanding

- Technical/ Laboratory skills

- Practical Application

- Team Working

- Communication/ Oral Skills

- Up to date to Modern technologies
-Writing Skills/ (Report, analysis...)

- Management skills

- Research and Innovative Ideas

- Problem Solving Skills

- Use of Statistics methods in evaluation

- Embark on training programs of postgraduate level 
5. According to you, from the given list, what are the skills and competences that you have not received and completed until now?

\begin{tabular}{|l|l|}
\hline 1 & \\
\hline 2 & \\
\hline 3 & \\
\hline 4 & \\
\hline 5 & \\
\hline
\end{tabular}

6. From your point of view, do you think you have achieved a good practical/ technical skill from the module you have completed till now?

$\square$ Yes $\square$ No

If No, what are the main constraints?

7. According to you, do you feel you have increased and upgraded your Team Working ability?

8. According to you, do you feel you have increase and upgrade your Communication skills?

Strongly Disagree

$\square$ Disagree

Neither Agree nor Disagree

$\square$ Agree

$\square$ Strongly Agree

From previous studies, it was found that the writing skills of students from BSc (Hons) Agriscience \& Technology was average and need more focus 
on it, do you feel your writing skills has evolved since starting the course? (Writing skills: Report, Dissertation, Assignment, portfolio)

$\square$ Strongly disagree

$\square$ Disagree

Neither Agree nor disagree

$\square$ Agree

Strongly Agree

10. According to you, do you feel you have received a good knowledge of Statistical Analysis to tackle the world's job market?

Strongly disagree

$\square$ Disagree

$\square$ Neither Agree nor disagree

$\square$ Agree

$\square$ Strongly Agree

\section{SECTION C}

11 According to you, do you feel that the course BSc (Hons) Agriscience \& Technology is up to date to our present modernised Agriculture?

$\square$ Yes $\square$ No

If No, what do you feel can be done?

12. What are the main constraints that you have underwent until now during the course? 
13. Would you recommend the course BSc (Hons) Agriscience \& Technology to future students starting their tertiary education?

$\square$ Yes $\square$ No

D) Survey of FoA Alumni

\section{UNIVERSITY OF MAURITIUS FACULTY OF AGRICULTURE}

Dear Sir/Madam, I am XXX, currently enrolled as full-time BSc student at the Faculty of Agriculture, University of Mauritius. In this respect, I am doing a survey on "FoA Alumni Student Satisfaction survey" so as to propose an innovative curriculum framework for the teaching of Agriculture sciences. I seek your valuable opinion in this research study. Your response will be of great help for this study. Note that the data collected will remain strictly confidential. Thank you for your assistance in my educational endeavors.

\section{SECTION A: DEMOGRAPHICS and QUALIFICATION}

1. Gender

$\square$ Male $\square$ Female

2. Age Group
口 18-25
26-30
口 31-40
41-50

3. Marital Status

$\square$ Married $\square$ Single

4. What level of Course have you followed at the Faculty?

$\square$ Certificate

$\square$ Diploma

$\square$ Undergraduate

$\square$ Postgraduate 
5. What course have you completed at the FOA?

\begin{tabular}{|l|l|}
\hline 1 & \\
\hline 2 & \\
\hline 3 & \\
\hline
\end{tabular}

6. In which year have you completed your course? Year:

\section{SECTION B - EMPLOYMENT}

6. Are you employed?
Yes
$\square$ No

If Yes, Where are you actually working?

7. How long did it take you to find a job since obtaining a degree?

8. Which one of the following best describes your current position with regard to paid work?

\begin{tabular}{|l|l|}
\cline { 2 - 2 } \multicolumn{1}{l|}{} & Tick \\
\hline Working Full time & \\
\hline Working part-time but seeking full-time work & \\
\hline Self-employed & \\
\hline
\end{tabular}




\begin{tabular}{|l|l|}
\cline { 2 - 2 } \multicolumn{1}{c|}{} & Tick \\
\hline Not working and looking for a job & \\
\hline Others, please specify below & \\
\hline
\end{tabular}

Others:

\section{$\underline{\text { SECTION C }}$}

According to the BSc (Hons) program of study, upon completion of the course, the graduate should have grasped all the learning outcomes as per his/her course. These are the main skills and Competences you should have grasped:

- Theoretical Understanding

- Technical/ Laboratory skills

- Practical Application

- Team Working

- Communication/ Oral Skills

- Up to date to Modern technologies
- Writing Skills/ (Report, analysis...)

- Management skills

- Research and Innovative Ideas

- Problem Solving Skills

- Use of Statistics methods in evaluation

- Embark on training programs of postgraduate level

9. Do you think that you have grasped all the learning outcomes listed after completion of your course?

10. According to you, what are the learning outcomes or skills that you have missed? Or not fully completed?

\begin{tabular}{|l|c|c|c|c|c|}
\cline { 2 - 5 } \multicolumn{1}{c|}{} & $\begin{array}{c}\text { Strongly } \\
\text { Disagree }\end{array}$ & Disagree & $\begin{array}{c}\text { Neither } \\
\text { Agree } \\
\text { Nor } \\
\text { Disagree }\end{array}$ & Agree & $\begin{array}{c}\text { Strongly } \\
\text { Agree }\end{array}$ \\
\hline $\begin{array}{l}\text { My student workload was } \\
\text { manageable }\end{array}$ & $\square$ & $\square$ & $\square$ & $\square$ & $\square$ \\
\hline
\end{tabular}




\begin{tabular}{|l|c|c|c|c|c|}
\cline { 2 - 5 } \multicolumn{1}{l|}{} & $\begin{array}{c}\text { Strongly } \\
\text { Disagree }\end{array}$ & Disagree & $\begin{array}{c}\text { Neither } \\
\text { Agree } \\
\text { Nor } \\
\text { Disagree }\end{array}$ & Agree & $\begin{array}{c}\text { Strongly } \\
\text { Agree }\end{array}$ \\
\hline $\begin{array}{l}\text { The quality of teaching } \\
\text { was satisfactory }\end{array}$ & $\square$ & $\square$ & $\square$ & $\square$ & $\square$ \\
\hline $\begin{array}{l}\text { The Learning } \\
\text { environment was } \\
\text { adequate }\end{array}$ & $\square$ & $\square$ & $\square$ & $\square$ & $\square$ \\
\hline $\begin{array}{l}\text { The work placement was } \\
\text { useful }\end{array}$ & $\square$ & $\square$ & $\square$ & $\square$ & $\square$ \\
\hline $\begin{array}{l}\text { The Faculty offers a wide } \\
\text { range of modules }\end{array}$ & $\square$ & $\square$ & $\square$ & $\square$ & $\square$ \\
\hline $\begin{array}{l}\text { The course was } \\
\text { valuable to me in my } \\
\text { professional and personal } \\
\text { development }\end{array}$ & $\square$ & $\square$ & $\square$ & $\square$ & $\square$ \\
\hline
\end{tabular}

11. Could you please, list some skills or attributes that are required at your enterprise/ Workplace that you did not receive upon completion of your course?

\begin{tabular}{|l|l|}
\hline 1 & \\
\hline 2 & \\
\hline 3 & \\
\hline 4 & \\
\hline 5 & \\
\hline
\end{tabular}

12. What is the main attribute or skill you have used at your workplace/ enterprise? 


\section{SECTION D- RELEVANCE OF TRAINING}

In this section, we aim to get your feedback on the study process you underwent at the Faculty

13. Please tick the appropriate box beside each statement that most accurately reflects your views on the training you underwent at the faculty

14. Please tick the appropriate box beside each statement that most accurately reflects your views on the study process you underwent at the FOA:

15. Would you recommend the FOA to anyone wishing to undertake an Undergraduate course?

Yes $\square$ No

Why? 
E) Survey on employers

\section{UNIVERSITY OF MAURITIUS FACULTY OF ACRICULTURE}

Dear Sir/Madam, I am XXX, currently enrolled as full-time BSc student at the Faculty of Agriculture, University of Mauritius. In this respect, I am doing a survey on "Assessing the level of Expectations of Employers/Stakeholders from students who graduated from BSc (Hons) Agriscience and Technology" so as to propose an innovative curriculum framework for the teaching of Agriculture sciences. I seek your valuable opinion in this research study. Your response will be of great help for this study. Note that the data collected will remain strictly confidential. Thank you for your assistance in my educational endeavors.

Name of your Organisation:

Address:

\section{SECTION 1: RECRUITMENT OF GRADUATES FROM THE FACULTY OF AGRICULTURE (FOA)}

This section asks for information regarding your organisation's employment of FoA graduates.

1. Does your Organisation recruit graduates from the Faculty of Agriculture? Yes $\square$ No

2. Do your employees possess a degree in BSc (Hons) Agriscience and Technology?
Yes
$\square$ No

3. How many of your employers from the FOA, have completed a $\mathrm{BSc}$ in Agriscience and Technology?

Number of graduates with BSc Agriscience and technology: .............

4. In what roles do you use those graduates within the first five years of their recruitment?

Technical $\square$ Teaching
Managerial
$\square$ Human Resource 


\section{$\square$ Health \& Safety Officer \\ $\square$ Others \\ $\square$ Research}

For Others; please specify:

5. How far are you satisfied with your employees from those graduates?

$\square$ Very Dissatisfied

$\square$ Slightly Dissatisfied

$\square$ Satisfied

$\square$ Slightly Satisfied

$\square$ Very Satisfied

\section{SECTION 2: ASSESSING THE QUALITIES AND COMPETENCES OF GRADUATES IN THE WORKING PLACE}

6. On a scale of (1-5), how satisfied is your organization with the following skills and competences from students graduated in BSc Agriscience and Technology?

\begin{tabular}{|l|c|c|c|c|c|}
\hline \multicolumn{1}{|c|}{$\begin{array}{c}\text { Skill and } \\
\text { Competences }\end{array}$} & $\begin{array}{c}\text { Very } \\
\text { Dissatisfied }\end{array}$ & $\begin{array}{c}\text { Slightly } \\
\text { Dissatisfied }\end{array}$ & $\begin{array}{c}\text { Neither } \\
\text { Satisfied nor } \\
\text { Dissatisfied }\end{array}$ & $\begin{array}{c}\text { Slightly } \\
\text { Satisfied }\end{array}$ & $\begin{array}{c}\text { Very } \\
\text { Satisfied }\end{array}$ \\
\hline $\begin{array}{l}\text { Theoretical } \\
\text { Understanding }\end{array}$ & 1 & 2 & 3 & 4 & 5 \\
\hline $\begin{array}{l}\text { Technical/ } \\
\text { Laboratory skills }\end{array}$ & 1 & 2 & 3 & 4 & 5 \\
\hline $\begin{array}{l}\text { Practical } \\
\text { Application }\end{array}$ & 1 & 2 & 3 & 4 & 5 \\
\hline Team Working & 1 & 2 & 3 & 4 & 5 \\
\hline $\begin{array}{l}\text { Communication/ } \\
\text { Oral Skills }\end{array}$ & 1 & 2 & 3 & 4 & 5 \\
\hline
\end{tabular}




\begin{tabular}{|l|c|c|c|c|c|}
\hline \multicolumn{1}{|c|}{$\begin{array}{c}\text { Skill and } \\
\text { Competences }\end{array}$} & $\begin{array}{c}\text { Very } \\
\text { Dissatisfied }\end{array}$ & $\begin{array}{c}\text { Slightly } \\
\text { Dissatisfied }\end{array}$ & $\begin{array}{c}\text { Neither } \\
\text { Satisfied nor } \\
\text { Dissatisfied }\end{array}$ & $\begin{array}{c}\text { Slightly } \\
\text { Satisfied }\end{array}$ & $\begin{array}{c}\text { Very } \\
\text { Satisfied }\end{array}$ \\
\hline $\begin{array}{l}\text { Writing Skills/ } \\
\text { (Report, analysis...) }\end{array}$ & 1 & 2 & 3 & 4 & 5 \\
\hline Management skills & 1 & 2 & 3 & 4 & 5 \\
\hline $\begin{array}{l}\text { Research and } \\
\text { Innovative Ideas }\end{array}$ & 1 & 2 & 3 & 4 & 5 \\
\hline $\begin{array}{l}\text { Problem Solving } \\
\text { Skills }\end{array}$ & 1 & 2 & 3 & 4 & 5 \\
\hline $\begin{array}{l}\text { Use of Statistics } \\
\text { methods in } \\
\text { evaluation }\end{array}$ & 1 & 2 & 3 & 4 & 5 \\
\hline $\begin{array}{l}\text { Up to date } \\
\text { to Modern } \\
\text { technologies }\end{array}$ & 1 & 2 & 3 & 4 & 5 \\
\hline $\begin{array}{l}\text { Overall } \\
\text { Performance }\end{array}$ & 1 & & 4 & 5 \\
\hline
\end{tabular}

7. What are the best attributes students from the course BSc (Aons) Agriscience and Technology possess?

\begin{tabular}{|l|l|}
\hline 1 & \\
\hline 2 & \\
\hline 3 & \\
\hline 4 & \\
\hline 5 & \\
\hline
\end{tabular}

\section{SECTION 3: ASSESSING SKILLS AND ATTRIBUTES OF GRADUATES}

8. According to you, what are the reasons why students graduating in the BSc (hons) Agriscience \& Technology have difficulties in finding a job? (You can have multiple answers)
$\square$ Lack of Experience and Skills
Not satisfied with salary
$\square$ Failed their interview
Not Proactive enough 
Lack of job Opportunities

Lack of Qualification

Overqualified
Lack of Team-Work

Lack of Theoretical Understanding Too much competition

9. According to you, are you satisfied with the skills and attributes of your employees, and if no, what do they lack?

\begin{tabular}{|c|c|c|c|c|}
\hline & \multirow[t]{2}{*}{ Skills and Attributes } & \multicolumn{2}{|c|}{$\begin{array}{l}\text { Are you satisfied with } \\
\text { this skill/ attributes } \\
\text { from your employees? }\end{array}$} & \multirow{2}{*}{$\begin{array}{c}\text { If No, } \\
\text { what } \\
\text { types of } \\
\text { skills do } \\
\text { they lack? }\end{array}$} \\
\hline & & Yes & No & \\
\hline 1 & Practical and Technical Skills & & & \\
\hline 2 & Communication Skills & & & \\
\hline 3 & Written/Report Writing Skills & & & \\
\hline 4 & Use of Statistics methods in evaluation & & & \\
\hline 5 & Theoretical Understanding & & & \\
\hline 6 & Management skills & & & \\
\hline 7 & Research and Innovative Ideas & & & \\
\hline
\end{tabular}

10. From your own perspectives, what are your expectations from graduates of BSc (Hons) Agriscience and Technology in terms of competences?

F) Survey on FoA Technicians

\section{UNIVERSITY OF MAURITIUS FACULTY OF ACRICULTURE}

Dear Sir/Madam, I am XXX, currently enrolled as full-time BSc student at the Faculty of Agriculture, University of Mauritius. In this respect, I am 
doing a survey on "Assessing Laboratory \& Technical competences acquired upon completion of BSc (Hons) Agriscience \& Technology" so as to propose an innovative curriculum framework for the teaching of Agriculture sciences. I seek your valuable opinion in this research study. Your response will be of great help for this study. Note that the data collected will remain strictly confidential. Thank you for your assistance in my educational endeavors.

Name of your Laboratory department:

\section{SECTION A - DEMOGRAPHIC INFORMATION}

1. Gender
Male
$\square$ Female

2. Age Group
$18-25$
26-30
31-40
ㅁ 41-50
51-60
$\square \geq 61$

3. At which department do you work?
APS
$\square$ AFS

4. In which laboratory do you work?

$\square$ Zoology Lab
$\square$ Microbiology Lab
$\square$ Soil Lab
$\square$ UOM Farm
$\square$ Biochemistry Lab

$\square$ Botany Lab
$\square$ Food Science Lab
$\square$ Animal Science Lab
$\square$ Biotechnology Lab
$\square$ Tissue Culture Lab

5. Do you work with students from the BSc (Hons) Agriscience and Technology Cohort?

$\square$ Yes $\square$ No 


\section{SECTION B - SATISFACTION OF SKILLS AND ATTRIBUTES}

6. Are you satisfied with the level of technical skills of current students in BSc (Hons) Agriscience and Technology?

Year 1:

$\square$ Very Dissatisfied

$\checkmark$ Slightly Dissatisfied

$\square$ Satisfied

$\square$ Slightly Satisfied

$\square$ Very Satisfied

Year 2:

$\square$ Very Dissatisfied

$\square$ Slightly Dissatisfied

$\square$ Satisfied

$\square$ Slightly Satisfied

$\square$ Very Satisfied

Year 3:

$\square$ Very Dissatisfied

Slightly Dissatisfied

$\square$ Satisfied

$\square$ Slightly Satisfied

$\square$ Very Satisfied

7. Do you feel that those students grasp all the necessary technical knowledge and skills for them to have a future job in the field of Agriculture?

$\square$ Really Disagree

Slightly Disagree

$\square$ Nor Agree nor Disagree

$\square$ Slightly Agree

$\square$ Really Disagree

8. According to you, are the apparatus found in your laboratory up-to-date with the modernized apparatus found in the workplace in the field of Agriculture?

$\square$ Yes $\square$ No $\square$ I Don't Know 


\section{SECTION C}

9. Could you please, list some technical skills and knowledge according to your field that students in BSc (Hons) Agriscience and Technology lack?

\begin{tabular}{|l|l|}
\hline 1 & \\
\hline 2 & \\
\hline 3 & \\
\hline 4 & \\
\hline 5 & \\
\hline
\end{tabular}

10. Could you list some Experiments or Analysis that students in BSc (Hons) Agriscience and Technology have difficulties to perform?

\begin{tabular}{|l|l|}
\hline 1 & \\
\hline 2 & \\
\hline 3 & \\
\hline 4 & \\
\hline 5 & \\
\hline
\end{tabular}

11. According to you, do you feel that those students acquire all the technical skills they should have to work for an enterprise or a Laboratory?

$\square$ Yes $\square$ No

If No, What skills do they lack? 


\section{SECTION D - SAFETY LEVEL IN LABORATORY OR UOM FARM}

12. Do current students have the knowledge about Hazard and Safety precautions in a laboratory or UoM Farm?

$\square$ Very Dissatisfied

Slightly Dissatisfied

Satisfied

$\square$ Slightly Satisfied

$\square$ Very Satisfied

13. According to you, do students in BSc Agri\&Tech respect the Hazard and Safety systems of Laboratories or UOM Farm?

$\square$ Yes $\square$ No

14. Can you please rate the Technical skills of the actual students enroll in the course BSc (Hons) Agriscience \& Technology? (Please tick one box only)

\begin{tabular}{|l|l|l|l|l|l|l|l|l|l|}
\hline 1 & 2 & 3 & 4 & 5 & 6 & 7 & 8 & 9 & 10 \\
\hline & & & & & & & & & \\
\hline
\end{tabular}




\section{The need to enhance the employability competences (knowledge, skills, autonomy, and attitudes) of undergraduates in Agriculture. Evidence from students' perceptions and employers' expectations}

Nigel Yoven Armoogum, Brinda Ramasawmy, and Brigitte Marie Françoise Driver*

\section{Copyright}

Copyright for this article is retained by the Publisher. It is an Open Access material that is free for download, distribution, and or reuse in any medium only for non-commercial purposes; provided any applicable legislation is respected, the original work is properly cited, and any changes to the original are clearly indicated. 